\title{
Religious conflict and regional autonomy in church establishment and Islamic clothing in West Pasaman and Dharmasraya West Sumatera
}

Nunu Burhanuddin

IAIN Bukittinggi Sumatera Barat

E-mail:nunu.burhanuddin@iainbukittinggi.ac.id

Ahmad Ali Nurdin

UIN Sunan Gunung Djati, Bandung

E-mail:ali.nurdin@uinsgd.ac.id

Muhammad Irfan Helmy

IAIN Salatiga

E-mail:mihelmy@iainsalatiga.ac.id

DOI: 10.18326/ijims.v9i2.189-216

\begin{abstract}
This paper analyses how religious minorities in West Pasaman and Dharmasraya have been disturbed by the implementation of regional autonomy policies. By examining the church establishment and Islamic clothing enactment in the region as case studies, the paper shows that the conflicts between Muslims and
\end{abstract}


Christians were caused by the discriminatory regional regulations against minority groups. This study uses an ethnographic approach, consisting of interviews and extensive observational research in the research site to collect the data. The article argues that the implementation of local government policies such as the very strict requirement to establish church and Islamic clothing regulations for students have negative impacts on the harmonious relationship between Muslims and non-Muslims in the region. Thus, local government officers should take into consideration minority and majority-group relationships in creating regional religious regulations.

Penelitian ini menganalisa bagaimana kaum minoritas agama di Pasaman Barat dan Dharmasraya terusik dengan implementasi kebijakan otonomi daerah. Dengan mengkaji aturan pendirian gereja dan busana Islami sebagai kasusnya, artikel ini menunjukkan bahwa konflik yang terjadi antara Muslim dan Kristen di daerah tersebut disebabkan karena regulasi otonomi daerah yang bersifat diskriminatif bagi kalangan kaum minoritas. Studi ini menggunakan metode etnografi dengan menggunakan wawancara dan observasi yang ekstensif di lokasi penelitian sebagai teknik pengumpulan data. Peneliti berargumen bahwa penerapan kebijakan pemerintahan local seperti ketatnya persyaratan membangun rumah ibadah (gereja) dan aturan kewajiban memakai busana Islam bagi pelajar mempunyai implikasi negative terhadap hu-bungan antara Muslim dan non-Muslim di daerah tersebut. Karenanya, pemerintah daerah harus berhatihati dan mempertimbangkan hubungan kelompok minoritas-mayoritas dalam membuat aturan daerah yang berhubungan dengan agama.

Keywords: Religious conflict; Regional autonomy; Church establishment; Islamic clothing

\section{Introduction}

Regional autonomy is one of the important changes in the governmental system in the Indonesian reformation era. This system diversifies an authority from the centralistic into a decentralized style in which several parties involved in operating the government. Scholars like Christopher 
R. Duncan ${ }^{1}$ and Simon Butt ${ }^{2}$ believe that there are advantages and disadvantages to this change. On the one hand, decentralization has built community participation and invited the widest possible public involvement in the planning, implementing and evaluating the processes of governmental policies. For this reason, decentralization provides a wider space for regions to regulate their own governance democratically as a manifestation of the ideals of decentralized system. ${ }^{3}$ Through fundamental changes in governance, the Regional Government has a great opportunity to build and determine the direction of their regional development. Through direct election mechanism, for example, regional leaders such as governors, mayors, and regents are required to run the government in an accountable, participatory, and transparent manner.

The system of decentralized government has actually been initiated by the founders of this country by putting forth one article in the $1945 .{ }^{4}$ The implementation of this article has always caused problems since the early years of national independence. The struggle to seek the meaning of nationalism seen as a secondary identity always faces the problem of primary identity in the form of strong solidarity of ethnicities, religions, customs, regional languages and traditions. These factors led to regional rebellions, for example Pemberontakan Pemerintahan Revolusioner Indonesia (PRRI) in Padang, West Sumatera on February 15, 1958. It also inspired similar movement from the region of North and Central Sulawesi. On February 17, 1958, these area declared their support for PRRI. ${ }^{5}$ It was also

${ }^{1}$ Christopher R. Duncan, "Mixed Outcomes: The Impact of Regional Autonomy and Decentralization on Indigenous Ethnic Minorities in Indonesia", Journal Development and Change, Volume 38,Number 4 (2007), 587-792.

${ }^{2}$ Simon Butt, "Regional Autonomy and Legal Disorder: The Proliferation of Local Laws in Indonesia", Singapore Journal of Legal Studies, (2010), 1-21.

${ }^{3}$ Ahmad Syafii Maarif, Islam Dalam Bingkai Keindonesiaan dan Kemanusiaan, Bandung: PT Mizan Pustaka, 2009, 178.

${ }^{4}$ See, The 1945 Constitution, article 18.

${ }^{5}$ Poesponegoro, Marwati Djoened and Nugroho Notosusanto.Sejarah Nasional Indonesia: 
followed the movement of Perjuangan Rakyat Semesta (Permesta) in Eastern Indonesia. In addition to the takeover of regional government by the military, these movements were also led by the inequality in the distribution of economic resources between the Central and Regional areas as well as the overly dominant power from the central government. ${ }^{6}$ Another factor was the hatred toward the Javanese as the most influential ethnic group in the newly formed state ${ }^{7}$ as well as demands for wider regional autonomy. ${ }^{8}$ The effect of this conflict in stills the thought about secession from the Unitary State of the Republic of Indonesia, and especially the demands for a more just distribution of political and economic power in the country. ${ }^{9}$

Since 1945, the Central Government has regarded plurality ambiguously, promoting the state official slogan of Bhinneka Tunggal Ika (Unity in Diversity) on one hand and implementing a policy of centralization on the other because diversity is seen as a threat of disintegration. At this point, decentralization aims to build community participation and invite the widest possible public involvement in the planning, implementing and evaluating the processes of the undertaken development. For this reason, decentralization provides a wider space for regions to regulate their own governance democratically as a manifestation of the ideals of decentralized system. ${ }^{10}$

Despite the aforementioned ideas, the implementation of this system faces substantial challenges. These challenges include (1) the unchanged

Zaman Jepang dan Zaman Republik Indonesia, Jakarta, PT. Balai Pustaka, 1992.

${ }^{6}$ Burghoom, Lundstorm. Minahasa Civilization: A Tradition of Change, Gotebeg: ACTA Universitais Gothoburgensis, 1981, p. 43.

${ }^{7}$ Schouten, M. J. C. Leadership and Social Mobility in a Southeast Asian Society: Minahasa 1677-1983, Leiden: KITLV Press, 1998, p. 215.

${ }^{8}$ Hakiem, Lukman (ed). M. Natsir di Panggung Sejarah Republik, Jakarta: Penerbit Republika, 2008.

${ }^{9}$ Hellstrom, Left. Air War in Paradise: the CIA and Indonesia 1958, Air Enthusiast, JulyAuguts 1999, p. 24-38.

${ }^{10} \mathrm{Ma}$ 'arif, Ahmad Syafii. Islam Dalam Bingkai Keindonesiaan dan Kemanusiaan, Bandung: PT Mizan Pustaka, 2009, p. 178. 
mind set or mentality of the bureaucratic apparatus; (2) the relationship between central and regional institutions; (3) limited human resources; (4) the power-oriented struggle of interest, asset control and the existence of some sort of power shift syndrome symptom among government officials; and (5) the government's desire to render the rural areas as a political unit rather than the socio-cultural unit with their autonomous social-cultural order. $^{11}$

Chauvinism emerged in the next era in the form of an extreme attitude toward a certain worldview without thinking the good aspects of other worldviews and extreme fanaticism on their regions, for instance the emergence of DI-TII local political group in West Java, Central Java, Aceh, South Sulawesi and Kalimantan. ${ }^{12}$ DI-TII movement started with the proclamation of Daud Beureuh in Aceh as the Islamic State of Indonesia under the leadership of Imam Kartosuwiryo. This movement that took place between 1953 and 1962 gave birth to militant figures who defiled NKRI, such as Daud Beureuh in Aceh, Ibnu Hajar in South Kalimantan in $1950^{13}$, Amir Fatah in Central Java, and Abdul Kahar Muzakar in South Sulawesi who was killed on February 3, 1965. Then, the PKI movement emerged which was triggered by propaganda about farmers who were entitled to every land regardless of the owner, which was then led to the widely spread clashes. This movement imitated the Bolsevik revolution in Russia. ${ }^{14}$

On the other hand, negative effects also appear in its implementation. These problems include social jealousy over the implementation of the

\footnotetext{
${ }^{11}$ Ahmad Syafii. Islam Dalam Bingkai.., p. 179.

${ }^{12}$ Cribb, Robert.Digital Atlas of Indonesian History, Copenhagen, Denmark : NIAS Press, 2010, p. 162.

${ }^{13}$ Singh, Bilveer. The Talibanization of Southeast Asia, Santa Barbara: Greenwood Publishing Group, 2007, p. 31.

${ }^{14}$ Crouch, Harold. The Army and Politics in Indonesia, New York: Cornell University Press, 1978.
} 
autonomous regional government. In Hal Hill's words, the regional autonomy has led to "inequality and local-level dynamics" 15 and according to Takahiro Akita, Puji Agus Kurniawan and Sachiko Miyata, it has brought "structural changes and regional income inequality in Indonesia." ${ }^{16}$ It is widely believed that the rampant issuance of Regional Regulations is problematic because they tend to prioritize the interests of Regional Leader Headswhich sometimes are in contradiction with the higher legislation. Tommy Firman states that regional autonomy has made "local government consider themselves of their own kingdom of authority." 17

In addition, when a centralized system has been changed into a decentralized one, the regions have been lacking in their preparation, particularly in terms of taking initiative in determining policies. The constraints of human resources, the interests of political power, and the control of regional assets are the main factors that overshadow the political actors in the regions. This is what happened in West Pasaman and Dharmasraya, the focus of this study.

This article examines to what extent the implementation of regional autonomy in West Pasaman and Dharmasraya has paved the way to conflict between minority and majority groups. This study uses an ethnographic approach. Interviews and extensive observational research in the research site have been done by the researchers in collecting the data. In this paper, we argue that the conflict in the regions related to the regulation issued at the local level that prohibits the establishment of a house of worship

${ }^{15} \mathrm{Hal}$ Hill, "Globalization, Inequality, and Local-Level Dynamics: Indonesia and the Philippines”, Asian Economic Policy Review, Volume 3,Number 1(2008), 2-61.

${ }^{16}$ Takahiro Akita, Puji Agus Kurniawan and Sachiko Miyata, "Structural Changes and Regional Income Inequality in Indonesia: A Bi-Dimensional Decomposition Analysis", Asian Economic Journal, Volume 25,Number 1 (2011), 55-77.

${ }^{17}$ Tommy Firman, "Decentralization Reform and Local-Government Proliferation in Indonesia”, Review of Urban and Regional Development Studies, Volume 21,Number 2(2009), $143-157$. 
(Church). Such conditions occur because this region is thick with its Minangkabau culture with its strong preference for sharia. This is in accordance with the custom of "Adat bersandikan syara', syara' bersandikan kitabullah", meaning that every Minangkabaunese is definitely Muslim. ${ }^{18}$ The religious conflicts in West Pasaman was also marked by the refusal of the renovation of the Church by Forum Komunikasi Ormas Islam (FKOI) in 2012 and the surrounding community in 2014. The discrimination against Christian minority is directly or indirectly triggered by the regional government in the name of regional autonomy. The same issue is also found in Dharmasraya where the establishment of a house of worship in Sungai Rumbai in 2005 and religious conflicts in the Oil Palm Plantation have occurred. The other discriminatory regional regulations such as the regional regulation on the obligation for students in elementary, junior, and senior high schools as well as employees to wear the Hijab, and local regulations on obligations to read and write the Quran for students would also be examined in this paper.

\section{Socio-religious mapping of West Pasaman and Dharmasraya}

West Pasaman is one of the regencies in West Sumatra, Indonesia. This area is formed from the division of Pasaman Regency based on Law no. 38, 18 December 2003 with the district capital at Simpang Ampek. ${ }^{19}$ West Pasamanis located on the border of West and North Sumatra. This is a small portrait of Indonesia that describes various kinds of ethnicities and religions. The peopleliving in West Pasaman are Minangkabaunese, Javanese and Mandailing, and Bataks. The major religion of society, in general, is Islam and Christianity. Islam is practiced by the Minangkabau

\footnotetext{
${ }^{18}$ Dt. Rajo Pengulu, Rangkaian Mustika Adat Basandi Syarak di Minangkabau, Padang: n.p., 1994, 64.

${ }^{19}$ Provinsi Sumatera Barat Dalam Angka, Sumatera Barat Provinces in Figures, BPS-Statistics of Sumatera Barat, 2016.
} 
and Mandailing ethnic groups and some Javanese while Christianity is practiced by most Javanese and Batak ethnic groups. It is worth mentioning here that the Mandailing ethnic is different from Bataks. ${ }^{20}$ The latter publicly claimed the Mandailing community as a sub-system of the Malay tribe, not Batak. While in terms of demographics, Mandailing community are used to be settled around the area called Batak land. Two tribes (Mandailing and Batak) in West Pasaman have great potential conflicts that have been inherited from time to time.

The religious relationship of Minangkabau people in Pasaman is strengthened by inter-ethnic marriage particularly between Mandailing and Minangkabau people. Acculturation occurs not only in marriage but also in other fields such as carpentry, crafts, and food. The Mandailing population in West Pasaman also build a lot of houses and mosques. Mandailing craftsmen collaborate with Minangkabau artisans. This collaboration works could be seen from the fact that architectural art and design of houses and mosques in Mandailing similar to those found in Pasaman or elsewhere in West Sumatra.

Dharmasraya is one of the regencies in West Sumatera Province established under Law no. 38 of 2003, and is a division of Sijunjung Regency. This regency is known as Ranah Cati Nan Tigo. This name is taken from the manuscript contained in the Padang Roco inscription, which mentions Dharmasraya as the capital of the Malay kingdom at that time. This kingdom emerged after the fall of the Srivijaya in the 13-14th century. ${ }^{21}$

The dominant religion of Dharmasraya community is Islam. Dharmasraya people treat Islam as their life guidance in addition to local

${ }^{20}$ Ida Liana Tanjung, Bambang Purwanto and Nur Aini Setiawati, "Colonial Politics in Forming Ethnic Identity of Melayu Minangkabau and Batak in Tapanuli", Humaniora, Volume 28,Number1 (2016),106-114.

${ }^{21}$ Provinsi Sumatera Barat Dalam Angka, Sumatera Barat Provinces in Figures, BPS-Statistics of Sumatera Barat, 2016. 
customs. Minangkabau people have the principle of "adat basandi syarak, syarak basandi kitabullah", meaning that adat is based on the Shari'a or religious law and the Shari'a is based on the Qur'an. ${ }^{22}$ Dharmasraya people are an egalitarian and open society. There is a pattern of openness in the social structure of Dharmasraya where immigrants are seen as a "protected" community based on social stratification law. In this area, social stratification is described by specific terms: (i) kamana kantali paruik, (ii) kamana kantali budi, and (iii) kamanakan bawah lutuik. The first group is a direct descendant of the first migrant family in the region called "urang asa" (the origin). The next group is a descendant of the family who came later, while the latter group is the descendant of those who live under the protection of urang asa. The openness of Dharmasraya community lies in another accommodation system of community that is attached to the original person, or called kamanakan bawah lutuik. This, of course, gives an opportunity for harmony in this area of Ranah Cati Nan Tigo.

\section{Religious conflicts within the framework of regional autonomy}

A primordialist view, on the one hand, says that conflicts can be traced back to the nature of humaninstincts and tribalism based on differences in language, race, kinship, temperament, and tradition. ${ }^{23}$ On the other hand, instrumentalist view rejects this opinion by emphasizing the flexible nature of ethnic identity that is commonly used, mobilized, and manipulated by elite groups and the state for certain political purposes. In this context, religious conflict is caused by temporary exclusion religious leaders and adherents; closed attitude and mutual suspicion among religions; excessive association with religious symbols; using religion as a tool; and other

\footnotetext{
${ }^{22}$ Franz von Benda-Beckmann and Keebet von Benda-Beckmann, Recreating the Nagari: Decen-tralisation in West Sumatra, Halle: MPI for Social Anthropology, 2001, 20.

${ }^{23}$ Esra Arcan, "Ethnic Identities and Conflict: Ethnic Conflict Prevention Approach of European Union”, Journal of Educational and Social Research, Volume 4,Number 1 (2014), 28.
} 
factors in the form of social, political and economic condition. Thus, what often happens are not religious conflicts but other conflicts using religious symbols as a means of generating group solidarity? ${ }^{24}$

Horizontal conflicts are also common among people with different backgrounds of interests, political, economic, and social aspects. ${ }^{25}$ The tendency for disintegration is greater when some regions have very different conditions of socio-economic progress. In other words, there is a wide gap among the people of the regions in terms of economic status. Therefore, to avoid disintegration, the government needs to carry out equitable development in all regions to realize balanced progress in all regions. ${ }^{26}$

The potential for horizontal conflict also often overshadows the establishment of ahouse of worship, not only for religious minority but also for religious majority in Indonesia. Although Muslims constitute the majority in Indonesia, there are some provinces or a regency where Muslim are a minority group such as in Bali (Hindu is a majority) and in West Papua(Christianity is the majority), and in East Nusa Tenggara (Catholic is the majority).

To overcome the emergence of the turmoil in the establishment of houses of worship, the government issued a Joint Regulation of the Minister of Religious Affairs and Minister of Domestic Affairs Number 9 and 8, 2006 (called Surat Keputusan Bersama or SKB), on the Implementation of Duties of the Head of Region or Deputy Head of Region in the maintenance of religious harmony, the empowerment of religious groups, and the establishment of houses of worship. The presence of this SKB

\footnotetext{
${ }^{24}$ Zeynep Kaya and Outi Keranen, "Constructing Identity through Symbols by Groups Demanding Self-Determination: Bosnian Serbs and Iraqi Kurds",Ethnopolitics, Volume14,Number 5 (2015), 505-512.

${ }^{25}$ Frances Stewart, "Horizontal Inequalities as a Cause of Conflict: A Review of CRISE Findings”, Background Paper for the World Bank's World Development Report, Centre for Research on Inequality, Human Security and Ethnicity (CRISE), Oxford University, 2011.

${ }^{26}$ Alberto Alesina, Enrico Spolaore, and Romain Wacziarg, "Economic Integration and Political Disintegration”, American Economic Review, Volume 90,Number 5 (2000), 1276-1296.
} 
relatively reduces tension and conflict among religious communities.

Some of the problems occurred in the establishment of a house of worship are the use of private residence as a place for regular worship without permission or recommendation from Forum Komunikasi Umat Beragama (FKUB). However, sometimes, FKUB itself seems to become a source of conflict when they reject to recommend a particular religious group to build a prayer house. ${ }^{27}$ Other problems feature the establishment of houses of worship for the adherents of minority religions. The survey conducted in 2009 by the Wahid Institute, recorded 21 cases of attacks, raids on homes, buildings, or places of worship, and refusal of the establishment of houses of worship. Then, Center for Religious and Cross Cultural Studies (CRCS) reported 18 cases of synagogues. Meanwhile, the results of police monitoring in the past few years have been prominently related to the problem of the establishment of houses of worship in the form of destruction, attacks and protests from other religious communities as many as 196 cases. Other data released by the Ministry of Domestic Affairs (Kemendagri) showed that there are around 3,143 regional regulations identified as problematic and potentially discriminatory.

\section{Conflict related to church Issues in West Pasaman}

West Pasaman community, as mentioned earlier, has different ethnics and religious groups. The community of West Pasaman consists of Minangkabaunese, Javanese, Bataks, Mandailing, and Sundanese with Muslims as the majority. Minangkabau people in West Pasaman are almost certainly 100\% Muslim. Meanwhile, the people from Java and Batak, especially in Kinali, Koto Baru, and Luhak Dua are divided into

\footnotetext{
${ }^{27}$ Minako Sakai and M. Falikul Isbah, "Locating the Causes of Religious Intolerance in Indonesia, State Policies, Faith Based Organisations and Islamic Educational Institutions", Workshop on Negotiating Diversity in Indonesia, Singapore Management University 5-6 November 2012, 4.
} 
two communities, namely Muslims and Christians. Other communities such as Sundanese are closer to Minangkabau community in Pasaman Barat, there are several old houses of worship. One of the small churches or chapels located in Wonosari subdistrict is in horrible condition. Based on the statement of Christian religious leaders in the area, they plan to renovate the chapel to be a permanent and suitable for worship activities. Sanuri, the Chaplain of Wonosari, West Pasaman, says:

"In our region, Wonosari, there are 20 Christians. we came to this area Since 1965- we call it "Wonosari", a name that reminds us of origin in Central Java. In this transmigration area, we once built small churches, or chapels. Until now, the chapel has never been renovated and refurbished as we aspire to. We want this chapel to be rebuilt so we can carry out proper religious activities. But until now, the renovation permit is not issued because it does not meet the administrative requirements as it should." 28

In an effort to renovate the chapel, the congregation appeals to the authorities and local figures in the area. This effort is then responded by Nagari through a memorandum of agreement between Nagari, traditional figures and religious leaders from two different religions. In the memorandum, it is decided that the Chapel located in Wonosari is allowed to be renovated as necessary as possible without permanent renovation. The result of this agreement is conveyed by Zaenal Abidin, Management of the Al-Mujahidin Mosque, which is located 150 meters from the location of the chapel.

"The result of the agreement between the religious leaders, ninik mamak, and the government approved the appropriate renovation of the chapel. In the meeting, it was decided that the damaged roof would be replaced by a new roof, the damaged wall would be replaced with a new wall but no foundation or new building." 29

\footnotetext{
${ }^{28}$ Interview with Sanuri, Chaplain of Wonosari, in West Pasaman, 02.10.2017.

${ }^{29}$ Interview with Zainal Abidin, Management of Al-Mujahidin Mosque of Wonosari, in West Pasaman, 02.10.2017.
} 
The above interview provides information on communication patterns and deliberations about their efforts in the renovation of the chapel. However, the facts on the ground indicate different conditions. The old chapel is renovated by building a solid and permanent foundation. This situation, of course, led to the conflict in the area; so the government apparatus represented by Kesbangpol asks the security forces to stop the chapel renovation that is considered to violate the agreement.

In addition, there are several permanent churches scattered in several Nagari in West Pasaman including Wirakarya church, Koto Baru church, Luhak Nan Duo Church, Sumber Agung church, Padang Candu Church and others. Some churches are permanent and good. Among these 8 churches located in 4 subdistricts, only one church was established with an official permit from the local government.

As it has been known in Indonesia, permit of church establishment in a predominantly Muslim area should meet relatively strict requirements as stipulated in the Regulation of the Minister of Religion and Domestic Affairs, Regulation at the Provincial and District levels to the subdistrict and nagari levels. The rules concerning the establishment of houses of worship are the same for all regions in the country based on the minister's decree.

One of the specific requirements to build a religious building is that the religious followers in the area should have at least 90 followers and they should have an endorsement from local officials. In some cases, fabricated names and signatures are given. As the Head of West Pasaman Kesbangpol said:

"We as government officials try to apply the basic rules regarding building permits for house of worship which according to the Ministerial Decree, in the area should have at least 90 followers and should be supported by 60 people from the surrounding community. These conditions are quite difficult to fulfil, and therefore the FKUB 
which is the partner of the government in the region has never given a recommendation for the permit to establish the church." ${ }^{30}$

The problem then is how if the establishment permit of the church is not issued while the demands and the right to worship must be fulfilled? How do government officials respond to this issue? The question is answered by the Head of Kesbangpol who says that if the permit is not obtained, then the government should provide a house of worship, not a permanent church. Houses of worship can be created in an ordinary building or a private residence.

The absence of permit to establish churches in some permanent churches in Wets Pasaman, except for the church in Padang Candu Kinali, have triggered the protests and conflict. Since the requirements to build a house of worship were not fulfilled, it is permissible to hold worship activities or religious congregation in non-religious places that replace the church. However, some permanent church buildings in West Pasaman built without a legal permit and it means violating the rules. The absence of permit for church establishment is indeed a problem for Christians, both Catholic and Protestant in West Pasaman. One of the churches with this problem is HKBP Ressort Pardomuan Nauli Church. One of the board members of HKBP says:

"The HKBP church located in Jambak area has a congregation of approximately 250 families and should be eligible for the establishment of a church. In the beginning, this church was an ordinary house positioned as a house of worship. Along with the difficulty in obtaining land permits and certificates for church buildings, the congregation's initiative is to make a land certificate in the name of the landowner who gives the land as the house of worship. This land was obtained from a grant from a former retired Army officer who had served here." ${ }^{31}$

\footnotetext{
${ }^{30}$ Interview with Edison Zelmi, Head of West Pasang Police, in West Pasaman, 31.09.2017.

${ }^{31}$ Interview with Rosmeri Napitulu, HKBP Pardomuan Nauli Church, in West Pasaman,
} 
Realizing the absence of the establishment permit, the congregation did their religious activities carefully in order not to disturb other religious believers in the area, as Rosmeri Napitupulu says:

"While conducting worship, we try to do it as quietly as possible. We carefully park our cars so we do not disturb communities around. Although we use loudspeakers in worship activities the sounds can only be heard inside the church. Although, next to our worship place there is a mosque where we sometimes could listen adzan (religious call) while we are doing our worship activities, and listen Quranic recitation; we already get used to it and do not feel disturbed." 32

The problem experienced by HKBP Ressort Pardomuan Nauli above is also experienced by the Catholic Church of Keluarga Kudus Mahakarya. The issue of a building permit is still unsolved. According to one of the priests of Mahakarya church, Parkalis Riswanto Halawa, the total number of congregations around the Mahakarya church is 261 familiesor about 893 people. The church congregation is generally a transmigrant community originating from Central Java. The transmigrant communities in the region have been living since1960s with the first arrival in $1953 .{ }^{33}$

The absence of a permit to establish the church led the church officials to seek an alternative licensing through the Provincial Diocese in the city of Padang. That is, the permit for the establishment of the Mahakarya church in Pasaman Barat,is attached to the permit of the provincial diocese. In this way, Mahakarya church congregation could hold their activities safely, as Parkalis says:

"Mahakarya Church is the center of activities for Catholic communities in West Pasaman. This church is at the parish level, a hierarchy in

\subsubsection{7.}

${ }^{32}$ Interview with Rosmeri Napitulu, HKBP Pardomuan Nauli Church, in West Pasaman, 02.10.2017.

${ }^{33}$ Interview with Paskalis Riswanto Halawa, Parish Secretary of Keluarga Kudus, Mahakarya Church West Pasaman, 02.10.2017. 
the Catholic system of religion. As one of the Parishes, Mahakarya Church oversees 10 stations, namely the lower level churches located in West Pasaman. Above the Parish is a diocese located in the city of the Province. In this case Mahakarya Parish is under the protection of the Padang Diocese, while the highest hierarchy is at the level of PGI centered in Jakarta." ${ }^{34}$

Under the umbrella of the provincial Parish and diocese, Mahakarya Church can organize worship activities and rituals without any obstacles. In addition, this church also organizes elementary school activities for Christian students in the region. The only church in West Pasaman that has obtained the permit is Padang Candu Kinali Church. This church keeps a dark history because in the decade of the 2000s there was a conflict between Christians and Muslims in the region. Formerly, the Candu Padang church was located next to the Jami' mosque, which was only separated by a 7-meter road. The distance between the two houses of worship is not more than 50 meters. At the beginning of the reform era, there was a conflict that caused the church to be burnt. From this conflict, the local government with the assistance of the TNI (Indonesian Army) made an effort to move the church so that the distance between the mosque and the church became approximately $1 \mathrm{~km}$. After the conflict, the TNI seeks to obtain permission for the establishment of the church.

\section{Conflict related to church issues in Dharmasraya}

Unlike in West Pasaman, conditions in Dharmasraya are relatively more conducive. Dharmasraya, dominated by the Minangkabau community, shows a more stable religious atmosphere because the number of adherents other than Islamis relatively small. Dharmasraya community consists of several ethnic groups, namely Minangkabaunese, Javanese, Bataks,

\footnotetext{
${ }^{34}$ Interview with Paskalis Riswanto Halawa, Parish Secretary of Keluarga Kudus, Mahakarya Church West Pasaman, 02.10.2017.
} 
Sundanese and a handful of Chinese descendants.

Between 2000 and2003, a migrant community from Batak submitted their applications to the local government to build their church. The application was rejected by the Regional Government because there was no land permit. Indeed, acquisition of a land certificate in Dharmasraya is relatively complicated because it must get approval for ninik mamak. Land is generally in the control of tanah ulayat (communal land). Even, the land for personal gain is difficult to obtain let alone for a church. ${ }^{35}$

Meanwhile, the need for a worship facility was urgent. It led to a riot around Sungai Rumbai as the basis of Christians who converted an ordinary house into a house of worship. The riot caused the house to be the target of burning and raid. Negotiations between government officials, adat elites, religious figures, ninik mamak and related parties have agreed to change the function of an ordinary house into a house of worship with the requirement not to show religious symbol.

The place of religious conflict in Dharmasraya can be narrowed and localized because of the dominance of the Dharmasraya Minangkabau community. The transmigrant community in Dharmasraya is more dominant than the Javanese Moslem community, and the people of Christian faith are concentrated in one area, Sungai Rumbai. ${ }^{36}$

Based on the information presented by Mendri Doni, Secretary of Nagari in Sungai Rumbai, the adherents of Christianity was quite a lot, but because of massive Islamic da'wahmovements in the area, the number of Christian followers reduces significantly because many of them converted to Islam, moved to become Muslims, and others moved to the Muaro Bungo region, the part of Jambi province.

Most of the land ownership in Dharmasraya is in the management of

\footnotetext{
${ }^{35}$ Interview with Khairuddin, Secretary Kesbangpol Dharmasraya, in Dharmasraya, 05.11.2017.

${ }^{36}$ Interview with Rinaldi, in Sungai Rumbai, 02.11.2017.
} 
tanah ulayat. It is owned by the respective indigenous people. The right to control this land is known as tanah ulayat. According to Gunanegara, ulayat right is a set of authorities and obligations of an adat community related to the land located within its territory. ${ }^{37}$ This practice makes it difficult for private ownership and, in turn, has an impact on the efforts to establish a house of worship for Christians.

In contrast to tanah ulayat, lands controlled by a particular adat, village land is one of the lands which constitute the village's overall rights. The adat lands themselves consist of the rights of indigenous people and individual rights, in which the rights of indigenous people consist of (1) ulayat rights, in the form of land rights, partnership rights, beschikkingrechts; (2) village rights, in the form of village ownership land, village treasury land, bengkok and ambtveld land. ${ }^{38}$ On the other hand, the right to worship for religious adherents must be facilitated by the government because it is regulated in the Law 1945 Article 29 "(2) The State guarantees the freedom of every citizen to embrace their respective religions and to worship according to their religion and belief".

Dealing with the efforts to integrate the two concepts, the establishment of a church for Christians who have difficulty obtaining land ownership rights or special conditions for the establishment of places of worship are not fulfilled. The scheme is to make an ordinary house or private residence a house of worship. Usually, the residence religious leaders are chosen to given the lack of space or distance to reach an official house of worship. It is done by a handful of citizens in Sungai Rumbai who made the house of his religious figure a house of worship. ${ }^{39}$

${ }^{37}$ Gunanegara, Hukum Pidana Agraria: Logika Hukum Pemberian Hak atas Tanah dan Ancaman Hukum Pidana, Jakarta: Tatanusa, 2017, 3.

${ }^{38}$ Gunanegara, Hukum Pidana Agraria..., 3.

${ }^{39}$ Interview with Mendri Doni, Secretary of Nagari Sungai Rumbai Timur, in Sungai Rumbai 02.11.2017. 
The general scheme to anticipate the difficulty of establishing permanent churches is to use ordinary buildings as a house of worship with no religious symbols. In the area of Sungai Rumbai, precisely in Jorong Sungai Rumbai Timur bordering with Jorong Bunga Kencana, there is a house of worship built by the community without using religious symbols. This simple building is made of wooden materials with a zinc roof.

"This house of worship is a substitute for a residential house that was previously used as house of worship. The house is owned by Tumpale Situmorang. This house is adjacent to the Islamic Elementary School which is managed by the people of Jorong Sungai Timur. To avoid the undesirable occurrence, the followers of Christianity then build a simple house of worship near the plantation where they work." 40

This initiative to build a simple house of worship is local wisdom of the followers of Christianity there. The experience with the riot in 2003 provides a lesson for this and should be avoided in the future. The experience of interacting with the majority of citizens is an important note to build a pattern of social relations based on harmony and peace.

A house of worship with no religious symbols is also found in the area of oil palm and rubber plantations in Dharmasraya. In one of plantation companies, precisely in Palm Plantation there is a house of worship of Christians. In the area of the plantation dominated by transmigrants from Batak and Nias,a simple house of worship stands without religious symbols. According to one housekeeper, who did not want to publish his identity, ${ }^{41}$ the establishment of this simple house of worship is the policy of the firms to provide a space of peace to the employees working on the estate. It is not easy to get this facility because the company has been working for a long time to get permission from the local government. The

\footnotetext{
${ }^{40}$ Interview with Dodi Nasti, Satpol PP in Sungai Rumbai Dharmasraya, 02.11.2017.

${ }^{41}$ Interview with one of the worship house officials at the PT Sumber Andalas Kencana Oil Palm Plantation (PT. SAK), 20.08.2017.
} 
local government accommodates the existence of this house of worship after obtaining assurance from the company. It does not put a religious symbol in front of the building. ${ }^{42}$

From the explanation above, it can be said that the permit for church establishment for the Christian community is difficult to obtain due to several factors, such as the absence of land ownership rights, the difficulty of obtaining recommendations from 60 local residents, and the objections of ninik mamak and adat elites. The problem of the difficulty in establishing this church or house of worship at any time can create conflicts when the interests of the congregation are not adequately accommodated.

\section{Conflict related to Islamic clothing in Pasaman and Dharmasraya}

The majority of people inWest Sumatra are Muslims who are guided by the slogan 'Adat Basandi Syara', Syara' Basandi Kitabullah: tradition founded upon Islamic law, Islamic law founded upon Quran." ${ }^{43}$ Through this slogan, Islamic perceptions are very strong in Minangkabau. Minangkabau ethnic and Islam are considered to be inseparable. ${ }^{44}$ In West Sumatra, there are 27 pieces of Sharia-based Regional Regulations ${ }^{45}$ and divided into four sections that are anti-immoralacts regulation, the obligation to read Quran, the Islamic clothing regulation and zakat regulation.

In direct observations conducted at several schools in Padang by Lembaga Survey Indonesia, Lembaga Studi, Advokasi Masyarakat, and, Jurnal

\footnotetext{
${ }^{42}$ Interview with Tukirman, one of the congregations in Oil Palm Plantation PT Sumber Andalas Kencana, 20.08.2017.

${ }^{43}$ Ramayulis, et al, Pemahaman Ninik Mamak Pemangku Adat Minangkabau Terhadap Nilainilai ABS-SBK, Padang, IAIN Imam Bonjol Press, 2009.

${ }^{44}$ AA Navis, Yang Berjalan Sepanjang Jalan: Kumpulan Karangan Pilihan, Jakarta: Grasindo, 1999, p. 12; Nori Anggraini, Pergerseran Nilai Budaya Minangkabau Dalam Novel Dari Surau ke Gereja karya Helmidjas Hendra, dan Novel Persiden karya Wisran, Jurnal Dinamika UMT, Vol I, No I, 2015, p. 67.

${ }^{45}$ Perda Syariah di Sumetera Barat. See: http://heru2273.blogspot.com/2014/04/perdasyariah-di-suma-tera-barat.html.
} 
Perempuan in 2008, Sudarto and his colleagues found all non-Muslim students in four schools observed wore Hijab during the school hours. The non-Muslim girls claimed to wear the Hijab because they were forced to follow school rules. However, the regulation was only the instruction from the Mayor of Padang to the education offices and not local regulations.

In its implementation, the policy on "school uniform" (read: Hijab, baju kurung, baju koko) that applies to all students without distinguishing their religion does not really cause protests or turmoil in the community. This policy is then followed by other regional governments of West Sumatra. It is recorded that Local Government in several regencies and cities has issued an appeal, rules and even the local regulations on Islamic clothing, such as Regional Governments of Tanah Datar (No. 451.4, 2001), Solok (No 6, 2002), Sawahlunto (N0. 2, 2003) and Pesisir Selatan (No. 22, 2003 and No. 4, 2005) concerning Islamic clothing.

The implementation of several regulations on Islamic clothing in the form of Governor appeal, Regent appeal, Mayor instructions and Regional Regulation allegedly involves all students in the school both Muslim students and non-Muslim students. There is actually a Pasaman Regional Regulation on Islamic clothing for students and employees. The main point of the regulation states: "Every junior high school (SLTP), senior high school (SMA) student and employee must wear Islamic clothing, while for the general public it is only an appeal." 46

In light of the implementation of these regulations, researchers interviewed several local figures, including religious figures among Christians - whose children are directly subjected to the content of the regulation. The Head of West Pasaman Kesbangpol, Edison Zelmi said:"The school uniform in the form of Hijab for girls and baju koko clothes for boys applies to all students in junior and senior high schools

\footnotetext{
${ }^{46}$ Pasaman Regional Regulation Number 22 of 2003, article 5.
} 
in West Pasaman, both Muslim and non-Muslim. There are no protests or objections from non-Muslim students." ${ }^{47}$ The same as Zelmi, Rosmeri Napitupulu, pastor assistant at HKBP Church, West Pasaman also said that: We do not mind with school uniform regulation for our children. It is fine. Our children wear Islamic clothes, and on Friday they boys wear baju koko. We do it as obedience to school to avoid conflict with the school or teacher. Basically, Hijab and baju koko are not a problem for our children. However, we hope that they will not wear these clothes (read: Hijab) when their photo are taken to be put in their official school certificate because it will obscure the identity of our children when they continue their study to college or when they apply to work." ${ }^{48}$

The positive opinions on the regulation above have been claimed by ordinary citizens as well. Rusmiati, a Christian citizen in West Pasaman for example said that "I think the rules about Islamic clothing for school uniform are not a burden to us. Our boys wear Islamic cloth every Friday." ${ }^{* 9}$ Basri, a Muslim citizen living around the Wonosari Chapel, Wonosari said: "I see Christian students wearing Hijab and baju koko to school. It does not matter I guess." 50 The same as Rusmiati and Basri, another citizen Nasakti said: "there are two Christian employees in our workplace. Every day, they dress like Muslim women in general by wearing a Hijab. I see them enjoying it and not showing the impression of coercion." ${ }_{1}$

From the explanation above, it is clear that the Regulations on School Uniform with Hijab and baju koko do exist, and are enforced in public schools in West Pasaman. This enforcement is specifically aimed at Muslim students. However, in practice non-Muslim students as well as non-Muslim

\footnotetext{
${ }^{47}$ Interview with Edison Zelmi, S.Stp, MM, Head of West Pasaman Kesbangpol, 30.09.2017.

${ }^{48}$ Interview with Rosmeri Napitupulu, pastor assistant at HKBP Church, West Pasaman, 02.10.2017.

${ }^{49}$ Interview with Rusmiati, a Christian citizen, West Pasaman, 01.10.2017.

${ }^{50}$ Interview with Basri, a Muslim citizen living around the Wonosari Chapel, Wonosari, 01.10.2017.

${ }^{51}$ Interview with Nasakti, Kasi Kesra Luhak Nan Duo, West Pasaman, 02.10.2017.
} 
workers are also forced or even willing to wear such clothes. There has been no chaos, conflict or open confrontation to the implementation of this regulation from minority students in West Pasaman and Dharmasraya. However, if it is not anticipated by a special article that gives "freedom of choice" for non-Muslim, the implementation of this law could be a potential conflict that weakens the long-standing harmony.

Islamic clothing regulation for students in Pasaman allegedly raises psychological and theological violence for non-Muslim students. It is indicated by the feeling of being forced to wear the Hijab to school experienced by Christian students. Initially, minority students were reluctant to wear the Hijab on the first day of school. But they were reprimanded their senior for not wearing the Hijab. The minority students claimed that they were non-Muslim. They can no longer use the same claim after the announcement from their headmaster that non-Muslim students are required to wear the Hijab. Although in the process of learning and other activities in schools Christian minority students have never received discriminatory treatment, they still regret the existence of Islamic clothing regulations. Being forced to wear Islamic clothes has to be experienced by the Christians in West Pasaman eventhough it is painful. The pain is also felt by minority groups because they can not do anything.

This condition differs greatly from Dharmasraya society. Non-Muslim communities in this area do not feel uncomfortable with the clothes worn. From field observation, there are not many non-Muslim students who wear Islamic clothes compared to those in other areas. Non-Muslim students dress general school uniforms in general, without wearing a Hijab. Meanwhile Muslim students wear baju koko Friday following the habits of other students. At this point, the regulation on Islamic clothing is treated differently between communities in West Pasaman and Dharmasraya. This difference is because the community of Christians in Dharmasraya 
is more concentrated in Sungai Rumbai Subdistrict, in some Nagari and Jorong only unlike those in West Pasaman where they are spread in various subdistricts and Nagari.

\section{Conclusion}

This research found that the issue of establishment of a house of worship for Christian minorities have triggered opposition from Muslim community because the establishment does not follow the rules and agreements initiated by the local government and related parties. We found that only one out of 10 churches built hasan official permit. This potential conflict could become chaotic if there is a clash action from the majority community in the area. At this point, the Regional Government, religious leaders, ninik mamak and Kerapatan Adat are required to maintain dialogue between different religious followers in order to build an "understanding" at all times.

The local regulation of wearing Islamic clothing for Muslims both students and employees in West Pasaman and Dharmasraya, based on Regional Regulations, have been enacted since 2003. Although not specifically applied to all students and employees, non-Muslims follow the rule because of the "fear" factor if not following it. This regulation has paved the way for the religious conflict in the area. Thus, it is important to note here that the local government official should be wise to create or enact local regulations particularly the religious local regulation.

\section{Bibliography}

Akita, Takahiro, Puji Agus Kurniawan, and Sachiko Miyata. "Structural Changes and Regional Income Inequality in Indonesia: A BiDimensional Decomposition Analysis", Asian Economic Journal, Volume 25, Number 1 (2011): 55-77.

Alesina, Alberto, Enrico Spolaore, and Romain Wacziarg. "Economic 
Integration and Political Disintegration", American Economic Review, Volume 90, Number 5 (2000): 1276-1296.

Anggraini, Nori. Pergerseran Nilai Budaya Minangkabau Dalam Novel Dari

Surau ke Gereja karya Helmidjas Hendra, dan Novel Persiden karya Wisran,

Jurnal Dinamika UMT, Vol I, No I, 2015

Arcan, Esra. "Ethnic Identities and Conflict: Ethnic Conflict Prevention

Approach of European Union", Journal of Educational and Social Research, Volume 4, Number 1 (2014): 27-37.

Beckmann, Franz von Benda and Keebet von Benda-Beckmann.Recreating the Nagari: Decentralisation in West Sumatra. Halle: MPI for Social Anthropology, 2001.

Burghoorn, Lundstorm. Minahasa Civilization: A Tradition of Change. Gothenburg: ACTA Universitais Gothoburgensis, 1981.

Butt, Simon. "Regional Autonomy and Legal Disorder: The Proliferation of Local Laws in Indonesia", Singapore Journal of Legal Studies, (2010): $1-21$.

Cribb, Robert. Digital Atlas of Indonesian History.Copenhagen, Denmark: NIAS Press, 2010.

Crouch, Harold. The Army and Politics in Indonesia. New York: Cornell University Press, 1978.

Duncan, Christopher R. "Mixed Outcomes: The Impact of Regional Autonomy and Decentralization on Indigenous Ethnic Minorities in Indonesia”, Journal Development and Change, Volume 38, Number 4 (2007): 587-792.

Firman, Tommy. "Decentralization Reform and Local-Government Proliferation in Indonesia", Review of Urban and Regional Development Studies, Volume 21, Number 2 (2009): 143-157.

Gunanegara. Hukum Pidana Agraria: Logika Hukum Pemberian Hak atas Tanah dan Ancaman Hukum Pidana. Jakarta: Tatanusa, 2017. 
IJIMS: Indonesian Journal of Islam and Muslim Societies, Volume 9, Number 2, December 2019: 189-216

Hakiem, Lukman(ed). M. Natsir di Panggung Sejarah Republik. Jakarta: Penerbit Republika, 2008.

Hill,Hal. "Globalization, Inequality, and Local-Level Dynamics: Indonesia and the Philippines", Asian Economic Policy Review, Volume 3 (2008): 2-61.

Kaya, Zeynep and Outi Keranen. "Constructing Identity through Symbols by Groups Demanding Self-Determination: Bosnian Serbs and Iraqi Kurds”, Ethnopolitics, Volume 14, Number 5 (2015): 505-512.

Maarif, Ahmad Syafii. Islam Dalam Bingkai Keindonesiaan dan Kemanusiaan. Bandung: PT Mizan Pustaka, 2009.

Navis, A.A.Alam Terkembang Jadi Guru: Adat dan Kebudayaan Minangkabau. Jakarta: Grafiti Pers, 1984.

Navis, A.A. Yang Berjalan Sepanjang Jalan: Kumpulan Karangan Pilihan, Jakarta: Grasindo, 1999.

Pengulu, Dt. Rajo. Rangkaian Mustika Adat Basandi Syarak di Minangkabau. Padang: n.p, 1994.

Poesponegoro, Marwati Djoened and Nugroho Notosusanto.Sejarah

Nasional Indonesia: Zaman Jepang dan Zaman Republik Indonesia.Jakarta: PT. Balai Pustaka, 1992.

Provinsi Sumatera Barat Dalam Angka, Sumatera Barat Provinces in Figures, BPS-Statistics of Sumatera Barat, 2016.

Ramayulis, et al. Pemahaman Ninik Mamak Pemangku Adat Minangkabau Terhadap Nilai-nilai ABS-SBK. Padang: IAIN Imam Bonjol Press, 2009. Sakai, Minako, and M. Falikul Isbah. "Locating the Causes of Religious Intolerance in Indonesia, State Policies, Faith-based Organizations and Islamic Educational Institutions", Workshop on Negotiating Diversity in Indonesia, 5-6 November 2012, Singapore Management University. Schouten, M. J. C. Leadership and Social Mobility in a Southeast Asian Society: Minahasa 1677-1983. Leiden: KITLV Press, 1998. 
Singh, Bilveer. The Talibanization of Southeast Asia.Santa Barbara: Greenwood Publishing Group, 2007.

Stewart, Frances. "Horizontal Inequalities as a Cause of Conflict: A Review of CRISE Findings", Background Paper for the World Bank's

World Development Report, Centre for Research on Inequality, Human Security and Ethnicity (CRISE), Oxford University, 2011.

Tanjung, Ida Liana, Bambang Purwanto and Nur Aini Setiawati. "Colonial Politics in Forming Ethnic Identity of Melayu Minangkabau and Batak in Tapanuli”, Humaniora, Volume 28, Number 1 (2016):106-114. Tempo, edisi 08 XXXVII/14, 20 April 2008.

\section{Interviews:}

Interview with Edison Zelmi, S.Stp, MM, Head ofWest Pasaman, 31.09.2017.

Interview with, Sanuri, one of the Management of Wonosari Chapel, West Pasaman, 01.10.2017.

Interview with, Zaenal Abidin, Management of Al-Mujahidin Mosqueof Wonosari, West Pasaman, 02.10.2017.

Interview with, Rosmeri Napitupulu, pastor assistant in HKBP Church, West Pasaman, 02.10.2017.

Interview with, Paskalis Riswanto Halawa, Parish Secretary of Keluarga Kudus, Mahakarya Church,West Pasaman, 02.10.2017.

Interview with, Khairuddin, Secretary of Kesbangpol Dharmasraya, Dharmasraya, 05.11.2017.

Interview with, Rusmiati, a Christian citizen in Wonosari Kinali,West Pasaman, 02.10.2017.

Interview with, Mendri Doni, a Secretary in Nagari Sungai Rumbay Timur, 02.11.2017.

Interview with, Dodi Nasti, Satpol PP in Sungai Rumbay Subdistrict Dharmasraya, 02.11.2017. 
IJIMS: Indonesian Journal of Islam and Muslim Societies, Volume 9, Number 2, December 2019: 189-216

Interview with, Sumber Andalas Kencana (PT. SAK), 20.08.2017.

Interview with, Basri, a Muslim Citizen in Wonosari and Transmigrantfrom Kendal Central Java, on 1 October 2017.

Interview with, Nasakti, Kasi Kesra Luhak Nan Duo Subdistrict West Pasaman, on2 October 2017

Interview with, Basri a Muslim citizen living around the Wonosari Chapel, Wonosari, 01.10.2017.

Interview with, Aminullah Salim, Management of FKUB DharmasrayaRegency, 02.10.2017.

Interview with, Eri Erizal, Kaur Nagari Sungai Rumabay Dharmasraya, 02.10.2017. 